\title{
Prevalence and Risk Factors of Cardiovascular Diseases in the Congo-Brazzaville Pygmies
}

\author{
Simplice Innocent Moussouami ${ }^{*}$, Eddie Janvier Bouhika ${ }^{1}$, Florent Nsompi ${ }^{1}$, \\ Jean Michel Bazaba Kayilou², François Mbemba', Alphonse Massamba² \\ ${ }^{1}$ The Effort Laboratory of Physiology, Biomechanics and Nutrition, Superior Institute of Physical Education, \\ University Marien NGOUABI, Brazzaville, Congo \\ ${ }^{2}$ Interdisciplinary Laboratory, Companies, Sport, Health and Development, National School of Administration \\ and Magistracy, University Marien NGOUABI, Brazzaville, Congo \\ Email: "yanneldry@gmail.com
}

Received 27 May 2016; accepted 4 July 2016; published 7 July 2016

Copyright (C) 2016 by authors and Scientific Research Publishing Inc.

This work is licensed under the Creative Commons Attribution International License (CC BY).

http://creativecommons.org/licenses/by/4.0/

(c) (i) Open Access

\begin{abstract}
Objective: To evaluate the prevalence and determinants of overall cardiovascular risk among the pygmies of Congo Brazzaville. Methods: Cross-analysis of anthropometric data, clinical and laboratory 273 indigenous subjects including 54 patients with cardiovascular disease (CVD) and 183 without CVD, aged 29 to 69 years. The cardiovascular risk stratification table WHO/ISH 2003 was used to assess overall cardiovascular risk level. Multiple logistic regression was used to assess the independent determinants of cardiovascular risk using the global left ventricular hypertrophy as a marker. Results: Fifty-four subjects had cardiovascular disease (CVD), including 31 women $(36.7 \%)$. They were aged $51.9 \pm 12.4$ years $(p<0.05)$ and showed a high blood pressure in shortlong (100 \pm 77 vs $32 \pm 48$ months; $p<0.001)$. It was also found a pulse pressure, PPO (58 \pm 8 vs 51 $\pm 4 \mathrm{mmHg}$ ). In multivariate analysis, HDL-C levels, fasting glucose, age greater than 50 years and the higher parity or equalizes to 5 among women have emerged as key determinants of CVD risk. Conclusion: Whatever the stage, arterial hypertension in this study is associated at the risk of cardiovascular diseases (CVD) high at the Pygmies of Congo, emphasizing the need for a more aggressive follow-up strategy.
\end{abstract}

\section{Keywords}

Cardiovascular Risk, Determinants, Prevalence, Pygmy Congo

\footnotetext{
"Corresponding author.
}

How to cite this paper: Moussouami, S.I., Bouhika, E.J., Nsompi, F., Bazaba Kayilou, J.M., Mbemba, F. and Massamba, A. (2016) Prevalence and Risk Factors of Cardiovascular Diseases in the Congo-Brazzaville Pygmies. World Journal of Cardiovascular Diseases, 6, 211-217. http://dx.doi.org/10.4236/wjcd.2016.67023 


\section{Introduction}

Cardiovascular diseases (CVD) represent worldwide the leading cause of death both in developed countries [1][3] and in developing countries [4] [5]. In Congo, hospital studies report a frequency of around 32.5\% [6]. The main factors involved are the bad habits (his meals above standards, red meat consumption...), the reduction of physical activity and the deterioration of the lifestyle. However, patients studied in most of these works come from Bantu ethnic groups scattered throughout the urban and rural areas of the country. But there is a segment of the Congolese population that is indigenous (or pygmy). It occupies at the habitat forests of the Congo Basin from the Atlantic to northern Congo. Its diet is based on consumption of game, fruit and vegetables with diversified hygienic. Indeed, the environment is not suitable for agriculture (apart from cassava and banana) and livestock, giving their consumption patterns.

Moreover, studies conducted by Makosso et al. [7] in pygmy areas along the Conkouati-Douli National Park, in the Mayombe forest, revealed that these populations lived in the whole of bushmeat. She was eaten fresh or smoked.

To better understand the nutritional quality of that meat fat, Mananga et al. [8] in their study of the physiochemical composition of these have found polyunsaturated fatty acid ratios (PUFA)/saturated fatty acids (SFA), $100 \mathrm{~g}$ meat, values of 0.40 to 0.826 for fresh meat and smoked meat. Now it is known that metabolic availability of PUFA has a major impact on human health and is linked among other changes, with mortality by cardiorespiratory disease?

Hence the interests of this study that fixed objectives are to evaluate the prevalence of cardiovascular diseases in the indigenous population of the Congo and to determine risk factors.

\section{Material and Methods}

\subsection{Physical Framework}

Located in the southwest part of Congo, the study area in the Mayombe forest extends between $3^{\circ} 23 \mathrm{~S}-4^{\circ} 18 \mathrm{~S}$ and $11^{\circ} 06 \mathrm{E}-11^{\circ} 43 \mathrm{E}$ [9]. It covers an area of 504,950 hectares [10]. His relief, Appalachian guy with metamorphic soils, sandy schist series, calcareous marl and shale and limestone, resulting in a rugged and dissected slopes and deep ravines and valleys. The Kouboula and Mavencée Mountains are the highest channels of the zone. In moist forests where these populations live, periods of water shortage will not normally last more than one month to two years. This forest has about 1600 espèces plants (80\% of which are endemic) and fauna full of more than 1000 species [10].

\subsection{Topics}

The study, transversal and case-control, took place from 21 October 2015 to 17 February 2016. The number of the indigenous population of the study area was based on statistical data from the capital of the District Madingou-Kayes, Kouilou Prefecture. In total, the census 2014 to 1756 evaluated 1246 subjects women. Subjects were recruited during a national campaign for health monitoring with medical vehicle, Congolese indigenous people, in villages or camps listed in the zone. In the study subjects from the Aboriginal population aged 29 to 69 years after history have been included, for our study. Any subject not belonging to the Bantu pygmy group was excluded from the study.

\subsection{Methods}

Determining the lifestyle was based on physical activity and tobacco consumption, practice commonly found in these populations. Data on the duration of high blood pressure (hypertension) and traditional antihypertensive medication were sought. The following measurements were performed in all patients after 12 hours fasting: triglycerides and blood sugar. The left ventricular hypertrophy $(\mathrm{LVH})$ was determined by electrocardiography (EEG-HVG) has been set for a higher value to $13 \mathrm{~mm}$ [11]. As diagnostic criteria, were considered hypertensive subjects with abdominal circumference (PA) was greater than or equal to $94 \mathrm{~cm}$ for women and $80 \mathrm{~cm}$ for men. Selecting threshold values for triglycerides are those greater than or equal to $1.69 \mathrm{mmol} / \mathrm{L}(150 \mathrm{ml} / \mathrm{dl})$ for hyperglycemia superiority or equal to $5.6 \mathrm{mmol} / \mathrm{L}(100 \mathrm{mg} / \mathrm{dl})$. As regards the pressure, it was selected for a systolic blood pressure (SBP) greater than or equal to $140 \mathrm{mmHg}$ or a diastolic blood pressure (PBO) greater than or equal to $90 \mathrm{mmHg}$. Ultimately, 237 subjects were recruited for this work, responding to the ethical 
guidelines of the National Ethics Committee on Research in Health Sciences (CNERSSA) and those of Helsinki II.

\subsection{Statistical Analysis}

Data are expressed as mean \pm SD or relative frequency (\%). The difference between quantitative variables, hypertensive versus non-hypertensive, made use of the U test of Mann Whitney Wilcoxon this for hematological variables and the Student's t test for anthropometric and hemodynamic. As regards the comparison of percentages, the McNemar test was used. The determinants of cardiovascular risk, taking into account the lifestyle, food (biochemical determinants) and the level of gravidity of women in forest environment were searched using a logistic regression analysis by the coast through ratio (OR) accompanied by a confidence interval (CI). p value $<0.05$ was accepted as statistically significant. All data were analyzed on the logiciel Mathcad 6.0, after input on Epi-Info version 12.5.1.

\section{Results}

Clinical and laboratory characteristics of hypertensives and non-hypertensives are shown in Table 1 and Table 2. Of the 237 examinees, 54 of them (22.8\%) had hypertension including 31 women (36.7\%). This prevalence varied between $37.0 \%$ and $14.8 \%$, the highest prevalence is found among their patients over 5 years of age (37.0\%) and lowest among those with concentrations of cholesterol/HDL exceeded $1.03 \mathrm{mmol} / \mathrm{L}$ (Table 3). Their average age was $59.1 \pm 12.4$ years. Mean BMI amounted to $27.2 \pm 4.1 \mathrm{~kg} / \mathrm{m}^{2}$ in hypertensive patients: 20.1 $\pm 0.5 \mathrm{~kg} / \mathrm{m}^{2}$ in others $(\mathrm{p}=0.038)$. Superiority in systolic blood pressure was observed in hypertensive: $152 \pm 11$ $\mathrm{mmHg}$ versus $124 \pm 8 \mathrm{mmHg}(\mathrm{p}<0.001)$ and diastolic blood pressure $(98 \pm 85 \pm 6 \mathrm{mmHg}$ against $2 \mathrm{mmHg} ; \mathrm{p}=$

Table 1. Anthropometric determinants of blood pressure of subjects studied.

\begin{tabular}{cccc}
\hline & Presence of CVD $(\mathrm{n}=54)$ & Lack of CVD $(\mathrm{n}=183)$ & $\mathrm{p}$ \\
\hline Sex, M/W & $31 / 23$ & $124 / 59$ & $\mathrm{p}<0.05$ \\
Age (years) & $59.1 \pm 12.4$ & $42.0 \pm 2.8$ & $\mathrm{p}<0.001$ \\
Physical activity (\%) & 15.8 & 84.2 & $\mathrm{p}=0.059$ \\
Smoking (\%) & 13.1 & 3.0 & $\mathrm{p}=0.038$ \\
BMI (kg/m²) & $27.3 \pm 4.1$ & $20.1 \pm 0.5$ & $\mathrm{p}=0.24$ \\
abdominal circumference (cm) & $78.7 \pm 5.1$ & $64.2 \pm 1.5$ & $\mathrm{p}=0.049$ \\
Report abdomen/hips & $1.36 \pm 0.04$ & $0.72 \pm 0.02$ & $\mathrm{p}<0.001$ \\
Pas (mmHg) & $152 \pm 11$ & $124 \pm 8$ & $\mathrm{p}<0.001$ \\
Pad (mmHg) & $98 \pm 6$ & $85 \pm 2$ & $\mathrm{p}=0.038$ \\
PP & $53 \pm 8$ & $51 \pm 4$ & $\mathrm{p}<0.05$ \\
FC (mmHg) & $80.2 \pm 11$ & $71.3 \pm 1.0$ & $\mathrm{p}=0.030$ \\
\hline HVG (\%) & 26.6 & 73.4 & \\
\hline
\end{tabular}

BMI: Body Mass Index; No: Systolic blood pressure; Pad: Systolic blood pressure; PP $^{\circ}$ arterial pulse pressure; FC: Heart Rate; HGV: left ventricular pressure.

Table 2. Biochemical determinants.

\begin{tabular}{cccc}
\hline & Presence of CVD $(\mathrm{n}=54)$ & Lack of CVD $(\mathrm{n}=183)$ & $\mathrm{p}$ \\
\hline Total cholesterol $(\mathrm{mmol} / \mathrm{L})$ & $4.11 \pm 0.67$ & $3.08 \pm 0.41$ & 0.0024 \\
LDL-C $(\mathrm{mmol} / \mathrm{L})$ & $3.01 \pm 0.09$ & $2.29 \pm 0.12$ & 0.015 \\
HDL-C $(\mathrm{mmol} / \mathrm{L})$ & $1.15 \pm 0.11$ & $0.91 \pm 0.06$ & 0.017 \\
TG (mmol/L) & $1.03 \pm 0.04$ & $0.90 \pm 0.08$ & 0.039 \\
Blood glucose (mmol/L) & $3.21 \pm 0.09$ & $1.83 \pm 0.12$ & 0.026 \\
\hline
\end{tabular}

LDL-C (mmol/L): Low-Density Lipoproteins in Cholesterol; HDL-C (mmol/L): lipoprotein-cholesterol in high density; TG (mmol/L): Triglycérines; CVD: Cardiovascular Disease. 
Table 3. Risk factors for cardiovascular disease.

\begin{tabular}{|c|c|c|c|c|c|}
\hline \multirow{2}{*}{ Risk factors } & \multirow{2}{*}{ Effective } & \multirow{2}{*}{ Prevalence (\% sur 54 ) } & \multicolumn{2}{|c|}{ Association with CVD $(n=183)$} & \multirow{2}{*}{ OR } \\
\hline & & & $\chi^{2}$ & $\mathrm{p}$ & \\
\hline Age $\geq 45$ years & 20 & 37.0 & 24.58 & 0.0001 & 2.84 \\
\hline Parity (women) $\geq 5$ & 16 & 29.6 & 12.81 & 0.001 & 3.56 \\
\hline Obesity (RAH $\geq 1.3$ ) & 14 & 26.0 & 10.47 & 0.001 & 4.31 \\
\hline Smoking & 13 & 24.0 & 9.62 & 0.001 & 3.32 \\
\hline Sedentary lifestyle & 11 & 20.4 & 8.81 & 0.001 & 2.15 \\
\hline $\mathrm{TTG} \geq 1.69 \mathrm{mmol} / \mathrm{L}$ & 8 & 14.8 & 7.25 & 0.039 & 2.17 \\
\hline
\end{tabular}

TTG: Triglycerides.

0.036). The finding was similar to pulse pressure $(53 \pm 51 \pm 8 \mathrm{mmHg}$ against $4 \mathrm{mmHg}$; $\mathrm{p}<0.05)$ and heart rate $(80.2 \pm 71.3 \pm 11 \mathrm{bpm}$ against $1.0 \mathrm{bpm} ; \mathrm{p}<0.001)$. In addition, the proportion HVG proved significantly higher in hypertensive patients: $73.4 \%$ versus $26.6 \%(\mathrm{p}=0.030)$.

Waist circumference and abdomen-hip ratio in hypertensive ranged respectively in hypertensive $78.7 \pm 5.1$ $\mathrm{cm}(\mathrm{p}=0.24)$ and $1.36 \pm 0.04(\mathrm{p}=0.043)$. Moreover, physical activity was more practiced by non-hypertensive patients: $84.2 \%$ against $15.8 \%$ for hypertensive. By cons, smoking was more found in hypertensive (13.1\% against $3 \%$ ) versus $26.6 \%$ with no significant difference $(\mathrm{p}=0.059)$.

\section{Discussion}

The aim of this study was to evaluate the prevalence of cardiovascular diseases and determine the risk factors in an Aboriginal population in Congo (Brazzaville). The main results show firstly that the prevalence is $22.8 \%$. This prevalence is lower than that found in the non-indigenous Congolese population: $32.5 \%$ in Brazzaville [6] and $36.4 \%$ in Pointe Noire [12].

Overall, the prevalence of patients with CVD was $29 \%$ for women against $20 \%$ for men. This varied significantly $\left(\chi^{2}\right.$ McNemar $\left.=6.01 ; \mathrm{p}=0.001\right)$ according to the association of risk factors. Regarding the latter, age greater than 50 years, the top parity or equal to 5 in women, physical inactivity, serum HDL cholesterol and higher glucose respectively $1.15 \pm 0.11 \mathrm{mmol} / \mathrm{L} 3.21 \pm 0.09 \mathrm{mmol} / \mathrm{L}$ were the main determinant in predicting CVD risk depend in Aboriginal populations studied. However, the interpretation of our results is facing some limitations which the first is related to the cross-sectional nature of the study. In addition, the targeted location in the study area to that of the southern part of the forest of Mayombe is a second limit. Indeed, the Congolese indigenous peoples are found in four areas: 1) forest part of the prefecture Lekoumou (border between Congo and southern Gabon); 2) northern West Cuvette the prefecture (northern border with Gabon); 3) the western part of the prefecture of Sangha (border with Cameroon); 4) northern prefecture of Likouala (bordering the Central African Republic). All these areas are integrated throughout the great Congolese forest basin (Cameroon, Congo, Gabon, Equatorial Guinea, Central African Republic, and Democratic Republic of Congo). Therefore, the data from this study cannot be extrapolated to all the indigenous peoples of the Congo. However, the fact that this work is the first of its kind in Central Africa is the power of this study.

The results show that CVD patients are older, which joined the literature data [13] [14]. Indeed, age is well known as primary risk factor for CVD [15], as the level of blood pressure is associated with old age. The deleterious effects induced by age on cardiac function are supposed to be related with cardiovascular remodeling processes [15]-[18] and the association of multiple risk factors [19]. Cardiovascular remodeling, according to several studies, is associated with arterial stiffness [18] [19] and the subsequent increase in pulse pressure, an important factor for CVD occurred [20]. In the present work, increased pulse pressure can be attributed to the negative impact of the aging process and the risk factors associated with the alteration of the blood vessels. Another explanation is the deficit of the differential control of systolic and diastolic blood pressure due to the high impact on the reduction of systolic blood pressure [21] [22].

In addition, our patients are characterized by high levels of LVH; however, these rates are lower than those reported in the literature in Congolese patients from both banks of the Congo River, hypertensive and not from indigenous populations: 53.3\% in the Republic of Congo [6] and 68\% in the Democratic Republic of Congo [23]. Nevertheless, the negative impact of aging and persistent high blood pressure associated with cardiovascular risk 
factors, may explain the observed increase in left ventricular mass [24]. In addition, the high value of blood pressure in subjects could induce insulin resistance often found in high blood pressure [25]. However, the use of traditional medication by our subjects, based on infusions of some bark and/or leaves of trees, probably have lower cardiovascular risk levels. Indeed, after many ethno botanical and pharmaceutical ethno surveys in the Congolese forest basin, it is reported the existence of anti hypertensive antipyretic plants used by traditional healers in these environments [26]. The Congolese forest is full of about forty kinds; some of them are endemic to the Congo. However, in vitro antihypertensive activity of various extracts of these plants on serum samples of hypertensive individuals in our sample does not allow objectified our hypothesis.

In regard to physical activity, it is weak in women, given their vested roles (maintains housekeeping, meal preparation, etc.). As against it is significantly higher in men, particularly those aged 20 to 50 years. It resulted in the forest hunting, including the slaughter of bush meat. This hunt is characterized by races fast slow pace on trips strewn with various pitfalls (lianas, dead tree trunks, etc.) and different topographies. In addition, physical activity related to hunting nowadays is more intense because of the growing demand for bush meat by vendors in urban areas [7]. Thus, when the animals disappear locally, indigenous hunters do not hesitate to venture farther and spend more time on hunting expeditions for the desired game. In this activity, are added those of leisure (traditional dances and games) considered by our people as a practical form of physical activity.

Compared with serum concentrations of HDL cholesterol and glucose values recorded in our patients amounted to $1.15 \pm 0.11 \mathrm{mmol} / \mathrm{L}$ and $3.21 \pm 0.009 \mathrm{mmol} / \mathrm{L}$ respectively. These HDL cholesterol concentrations are a risk factor for CVD. The results of Mananga et al. [8] on the chromatographic profile of the AG of the oil extracted from the fresh bush meat in this direction. Indeed, the existence of the C10:0 in the second position is not nutritionally beneficial because its presence exposes the individual to the risk of hypercholesterolemia and atherosclerosis. By cons, other authors report that high concentrations of HDL-c provide protection against CVD by inhibiting the oxidation of LDL cholesterol [27]. This fact is also suggested for high glucose concentrations. Finally, this protective effect, apparently paradoxical, can be attributed to epidemiological phenomenon unlike traditional risk factors found in chronic diseases [28].

\section{Conclusion}

The present study has shown, despite some limitations, that cardiovascular diseases in Aboriginal populations have a relatively high prevalence, especially among women. Risk factors are within the food and the quality of life. However, data from this study need to be confirmed and validated by other more elaborate works, including a more representative sample of hypertensive patients from different walks of life of the Congolese indigenous people.

\section{Conflicts of Interest}

No.

\section{Author Contributions}

MSI designed the study and participated in the implementation of the experimental procedure. BKJM was involved in the acquisition of field data. MF has validated the experimental procedure and wrote the first version of the article. MA performed the statistical analysis of data and reread the final version of the article.

\section{References}

[1] Kotseva, K., Wood, D., De Bacher, G., De Bacher, D., Pyrörala, K., Keil, U. and Euroaspire Study Group (2009) Cardiovascular Prevention Guidelines in Daily Practice: A Comparison of EUROASPIRE I, II and III Surveys in Eight European Countries. Lancet, 373, 929-940. http://dx.doi.org/10.1016/S0140-6736(09)60330-5

[2] Kizer, J.R., Arnett, D.K., Belle, J.N., Paranecas, M., Rao, D.C., Provice, M.A., et al. (2004) Differences in Left Ventricular Structure Entre Black and White Hypertensive Adults. The Genetic Hypertension Epidemiology Network Study. Hypertension, 43, 1182-1188. http://dx.doi.org/10.1161/01.HYP.0000128738.94190.9f

[3] Chobanian, A.V., et al. (2003) The Seventh Report of the Joint National Committee on Prevention, Detection, Evaluation, and Treatment of High Blood Pressure: The JNC 7 Report. JAMA, 289, 2560-2572. http://dx.doi.org/10.1001/jama.289.19.2560 
[4] Lemogum, D., Seedat, Y.K., Mabadeje, A.F.B., Mendes, S., Bovet, P., Onwuhere, B., et al. (2003) On Behalf Facility of the International Forum for Hypertension Control and Prevention in Africa (IFHA). Recommendation for Prevention, Diagnostis and Management of Hypertension and Cardiovascular Risk Factors in Sub-Saharan Africa. Journal of Hypertension, 21, 1993-2000. http://dx.doi.org/10.1097/00004872-200311000-00003

[5] Katchunga, P.B., M’Buyamba Kabangu, J.R., Masumbuko, B.E., Lemogoum, D., Kashongwe, Z.M., Degaute, J.P., et al. (2011) Hypertension in Adults Congo South Kivu: Results of the Study VITARAA. Presse Médicale, 40, e315e323. http://dx.doi.org/10.1016/j.lpm.2010.10.036

[6] Kimbally-Kaky, G., Gombet, T., Bolanda, J.D., Voumbo, Y., Pkili, B. and Ellenga Mbolla, B. (2006) Prevalence of Hypertension in Brazzaville. Tropical Cardiology, 32, 43-45.

[7] Georges, M.-V., Alphonse, M., Joachim, M. and Thomas, S. (2012) Wildlife Lasting the Management the Long of the Conkouati-Doyli National Park Coastline to Congo-Brazzaville. International Journal of Molecular Zoology, 2, 55-61.

[8] Mananga, V., MakossoVheiye-G, Massamba, A., Massamba, J., Kinkela, T., Mbemba, F. and Silou, T. (2009) Influence of Smoking on Physiocochimique Composition and Nutritional Quality of Garisses Case African Éthérure. Annals of African Medicine, 3, 337-345.

[9] Heckerweiler, P. (1989) The Conservation of Forest Ecosystems of the Congo. IUCN, Gland (Switzerland and Cambridge), $187 \mathrm{p}$.

[10] Moutsambote, J.M. and Sita, P. (1996) Conkouati Reserve (Northeast, Cotovindou). PROGECAP/GEF Congo Scientific Report, 39 p.

[11] Kreutzenberg, S.V., Avogaro, A., Tienno, K. and Del Prato, S. (2009) Left Ventricular Mass in Cardiovascular Diseases. A Study Employing a Single ECG Index: The Cornell Voltage Index. Journal of Endocrinological Investigation, 22, 139-144.

[12] Kimbally Kaky-G, Gombet, T., Bolanda, J.D., Voumbo, Y., Pkili, B. and Ellenga Mbolla, B. (2009) Prevalence of Hypertension in Pointe-Noire. Too Cardiol, 42, 31-36.

[13] Ritz, E. (2007) Total Cardiovascular Risk Management. American Journal of Cardiology, 100, 53-60j. http://dx.doi.org/10.1016/j.amjcard.2007.05.015

[14] Benetos, R. (2002) Influence of Age, and Cardiovascular Disease Risk Factoring on Arterial Stiffness: Clinical Implications. American Journal of Hypertension, 15, 1201-1208. http://dx.doi.org/10.1016/S0895-7061(02)03029-7

[15] Tuomilehto, P. (2011) Impact on Cardiovascular Risk: Placation for Disease Management. Atherosclerosis, 5, 9-17. http://dx.doi.org/10.1016/j.atherosclerosissup.2004.03.006

[16] Kenchaiab, S. and Pfeifer, M.A. (2008) Cardiac Remodeling in Systemic Hypertension. Medical Clinics of North America, 96, 115-130.

[17] Plant, G.E. (2013) Impact of Aging on the Body Vascular System. Metabolism, 62, 31-35.

[18] Smith, S.M. and Mensah, G.A. (2013) Aging Population and Implications for Cardiovascular Disease Epidemic in Sub-Saharan Africa. Ethnicity \& Disease, 23, S77-S80.

[19] Ramos, M.J., Basagana, X., Sala, J., Masia, R. and Elesua Redicor Investigators (2004) The Role of Aging in Cardiovascular Risk Clustering Factoring in on Diabetes Population Free of Coronary Heart Disease. European Journal of Epidemiology, 109, 15-19.

[20] Dart, M. and Kinwall, B.A. (2012) Pulse Pressure. Review of Mechanisms and Clinical Relevance. Journal of the American College of Cardiology, 45, 775-784.

[21] Cushman, W.C. (2003) The Burden of Uncontrolled Hypertension: Ùorbidity and Mortality Associated with Disease Progtression. The Journal of Clinical Hypertension, 5, 14-22. http://dx.doi.org/10.1111/j.1524-6175.2003.02464.x

[22] Lloyd-Jones, D.M., Evans, J.C., Larsa, M.G., O’Donnell, C.J., Reccela, E.J. and Levy, D. (2000) Differential Control of Systolic and Diastolic Blood Pressure. Factors associated with the Lack of Blood Pressure Control. Hypertension, 36, 594-599. http://dx.doi.org/10.1161/01.HYP.36.4.594

[23] Lepira, F.B., Kayembe, P.K. and M’Baujamba-Kabanga, J.R. (2009) level and Predictors of Overall Cardiovascular Risk Untreated among Newly Diagnosed and Treated Black Patients with Arterial Hypertension. Annals of African Medicine, 2, 157-163.

[24] Varagi, C. (2010) Heart, Aging and Hypertension. Current Opinion in Cardiology, 16, 336-341. http://dx.doi.org/10.1097/00001573-200111000-00004

[25] Pontrmoli, R., Leoncini, G., Viazzi, F., Paoli, D., Vaccaro, V., Falqui, V., et al. (2004) Role of Insulin Resistance in the Assessment of Cardiovascular Risk in Essential Hypertension. Journal of Cardiovascular Risk, 149-153.

[26] Akendengue, B. (1992) Medical Plants Used by the Fang Tradional Healers in Equatorial Guinea. Journal of Ethnopharmacology, 37, 167-173. http://dx.doi.org/10.1016/0378-8741(92)90075-3 
[27] Zhang, B., Bai, H., Liu, R., Kumagai, K., Itabe, H., Takana, T. and Saku, K. (2004) Serum HDL-C Levels Modify the Associate Entre Plasma Levels of Oxidatively Modified LDL-C and Cardiovascular Disease in Men. Metabolism, 53, 423-429. http://dx.doi.org/10.1016/j.metabol.2003.10.028

[28] Kalantar Zadeh, K., Kilpatrick, R.D. and Wu, D.Y. (2004) Reverse Epidemiology of Conventional Cardiovascular Risk Factoring in Patients with Chronic Heart Failure. Journal of the American College of Cardiology, 43, 1439-1444. http://dx.doi.org/10.1016/j.jacc.2003.11.039

\section{Submit or recommend next manuscript to SCIRP and we will provide best service for you:}

Accepting pre-submission inquiries through Email, Facebook, Linkedin, Twitter, etc A wide selection of journals (inclusive of 9 subjects, more than 200 journals)

Providing a 24-hour high-quality service

User-friendly online submission system

Fair and swift peer-review system

Efficient typesetting and proofreading procedure

Display of the result of downloads and visits, as well as the number of cited articles

Maximum dissemination of your research work

Submit your manuscript at: http://papersubmission.scirp.org/ 